\title{
Herbart om oppdragelse, formbarhet og takt
}

\author{
Lars Løvlie*, \\ Institutt for Pedagogikk, Universitetet i Oslo, Oslo
}

\begin{abstract}
Sammendrag
Jeg presenterer her en analyse og tolkning av Herbarts syn på oppdragelse og danning, med feste i to av hans begreper: formbarhet - Bildsamkeit - og takt. Det første kaster lys over forholdet mellom lærer og elev, det andre først og fremst over forholdet mellom teori og praksis. For ham, som for forgjengeren Immanuel Kant, dreiet det seg om subjektivitet og frihet, eller mer konkret: Hvordan oppdra til autonomi der det også kreves tvang? Så vidt jeg kan se, bruker Herbart de to grunnbegrepene nettopp til å bestemme det paradoksale og uferdige forholdet mellom frihet og tvang. Han forklarer det som et åpent forhold eller relasjon som ikke har en bestemt begynnelse og heller ikke en bestemt konklusjon. Verken tradisjon eller vitenskap kan ved seg selv realisere dette råderommet. Han tenker seg et frirom der kunnskap, intuisjon og skjønn spiller på lag i oppdragelsen. Tradisjonen henger gjerne igjen i gamle fordommer, vitenskapen fanges i teori og abstrakt skjema, og ingen av dem dekker de unike situasjonene som nyskaper forholdet mellom voksne og barn. Herbart stilte seg åpen til spørsmål som ikke løses ved styring og kontroll, og spør implisitt om ikke vi også kan gjøre det samme.
\end{abstract}

Nøkkelord: pedagogikk; oppdragelse; formbarhet; takt; teori og praksis

Received: March 2015; Accepted: March 2015; Published: April 2015

\section{Innledning}

Noen kjenner til navnet Herbart og forbinder det med pedagogikk, færre har lest ham, og noen få har skrevet mer inngående om ham. Det som følger er en kritikk av to nøkkelbegreper hos denne tenkeren, formbarhet og takt. Kritikk brukes da om analyse og tolkning eller utlegning av tekster. Ordet kommer fra gresk krinein, som betyr å skille fra hverandre, å skjelne mellom ting, i dette tilfellet mellom tradisjon og nyskaping, rimelig og urimelig pedagogisk tenkning, men også i betydningen ta avstand fra eller avvise. I boken Om pedagogikk tar Immanuel Kant (1724-1804) opp om motsetningen mellom to viljer: den voksnes vilje til å oppdra og barnets gryende trang til selvstendighet. Enhver som har opplevd barn i den såkalte trassalderen, ser at trangen til selvstendighet kan føre til en kamp mellom viljer. Oppdragelse er nødvendig, men motsetningsfylt og derfor ingen likefram sak, mente Kant.

^Korrespondanse: Lars Løvlie, Institutt for Pedagogikk, Universitetet i Oslo. Postboks 1092, 0317 Blindern, Oslo. E-post: lars.lovlie@iped.uio.no 


\section{Løvlie}

Grunntanken hans er at autonomi - som betyr selvlovgiving - ikke kan være noe de voksne putter i barnet som et stykke kunnskap, men bør oppfattes som barnets eget verk. Det henger sammen med hans idé om et «myndig» menneske som tilskrives evnen til fritt, det vil si fornuftig og etter allmenne regler, å velge mellom å handle moralsk eller ikke. Tilskrivelsen er ikke empirisk, for erfaringen viser jo at barn reelt sett ikke er autonome, men trenger de voksne for å nå fram til selvstendighet. Tilskrivelsen er tankemessig og hører til refleksjonen over hva det er å være barn og voksen i den moderne verden. Kant opererte med to verdener som ikke kan reduseres til hverandre: den ene er tenkningens verden, den andre til tingenes og handlingens verden. Det skapte problemer som han ble kritisert for. Johann Friedrich Herbart (1776-1841) avviste denne to-verden-læren, og satte den som en forskjell eller distinksjon innenfor én verden - den vi faktisk lever i til daglig. Det hører til hans realisme, og den inneholder to sentrale begreper: formbarhet og takt. Det første kaster lys over forholdet mellom lærer og elev, det andre først og fremst over forholdet mellom teori og praksis.

Et lite tilbakeblikk viser at Kant tenkte seg en person som ikke går opp i naturen (bestemt av lyster) og heller ikke i kulturen (bestemt av plikter), men som altså er selvbestemt og «myndig», og i den forstand fri som voksen. Synspunktet fører ikke, som en kanskje kunne tro, til en egoistisk selvsentrering, men tvert om til et samfunn av borgere som makter å ta de andres standpunkt og øve selvkritikk og bruke dømmekraft. Hans idé om det subjektive som autonomi befrir tenkningen fra å gå helt opp i sine omgivelser og bare gjenta tradisjonen: og det er subjektet som paradoksalt nok skaper den avstand og motstand som gjør samfunnets selvkritikk mulig: dissenteren er ikke bare bråkmaker, men også samfunnets fornyer. La meg minne om at det var kvekerne, en engelsk lavkirkelig bevegelse, som fra 1750 gikk til kamp mot slavehandelen mellom Afrika og Amerika, med argumentet at alle mennesker var like overfor Gud. For Herbart dekket ikke motsetningen mellom indre frihet og ytre tvang hele det pedagogiske bildet. Viktigere var det treleddete forholdet mellom læreren, eleven og fagstoffet, slik det framstilles i den didaktiske trekanten. Han ble inspirert av Kants tanker om den estetiske oppdragelsen, der motsetningen mellom mesterens og lærlingens perspektiver harmoniseres ved at sistnevnte utfordres til å finne kunstens ideal i seg selv. Men kunstens ideal forutsetter kunstens realitet, at det faktisk finnes kunst og kunstnerisk virksomhet. Hva så hva med kunstneren i oss, enten vi er barn eller voksne. Det går en linje fra Kants idé om reflekterende dømmekraft - den som finner opp eller skaper regler - til Herbarts begrep om takt som den enkeltes frihet til å handle nettopp når reglene ikke strekker til, altså om det vi kaller skjønn. Takt har da ikke med takt og tone å gjøre, for her finnes jo faktiske regler for rett oppførsel, men om den besværlige motsetningen mellom teori og praksis, der hvert område kan ha sine særegne regler, mens forholdet mellom dem ikke har det. Motsetningen gjelder nå forholdet mellom to institusjoner: vitenskapelig tenkemåte og profesjonell praksis. Før jeg kommer så langt må vi se på Herbarts grunnleggende begrep om formbarhet eller Bildsamkeit som en egenskap ved eleven. 


\section{Herbarts kritikk}

Herbart godtok Kants alminnelige moralsyn, men hadde vansker med en filosofi som drev for hard enveiskjøring fra abstrakte prinsipper («Du skal ikke lyve!») til konkrete, dagligdagse situasjoner. Siden Kant knapt brydde seg med følelser, behov og lyster, fikk han ikke tak i den verden vi går og trår i, mente Herbart. En tenkning fri fra lidenskaper og interesser forblir en fattig tenkning. Han ville ha moralen tilbake $\mathrm{i}$ dagliglivet, og han ville nok gått god for verdisettet $\mathrm{i}$ den norske skolens formålsparagraf. Paragrafen - og jeg holder meg til de to første avsnittene er jo abstrakt i betydningen at for eksempel menneskeverd, solidaritet og nestekjærlighet ikke er fakta, men verdier som vi har skapt og holder i hevd. Samtidig finnes verdiene som holdninger, lærerne forholder seg aktivt til dem, og de er ment å skulle virke $\mathrm{i}$ den faktiske verden. Nå opptrer ikke verdiene nødvendigvis som imperativer eller grunnregler av typen «Du skal ...!», og de realiseres i hvert fall ikke ved en flervalgsprøve i etikk. De er snarere kriterier som vi kan prøve fakta mot, da inngår de i en kritisk diskusjon eller diskurs. Vi vil menneskeverd også der det ikke praktiseres, og kanskje nettopp da, med kampen for menneskerettigheter som eksempel. Ettersom verdier omfatter en blanding av prinsipper, holdninger og handlinger, bestemmer de ikke autoritært og direkte, men indirekte gjennom tolkning og anvendelse. Sånn sett avviker formålsparagrafen i den norske opplæringsloven fra resten av loven, som styrer skolen og er direkte juridisk forpliktende. Paragrafen bestemmer generelt mens resten av opplæringsloven styrer spesielt. Sagt på en annen måte: det finnes ingen streng logisk avledning fra verdiparagrafen, den første i opplæringsloven, og de påfølgende paragrafene. Formålsparagrafen gjelder sui generis, det vil si i sin egen rett, som uttrykk for Norges feste i den europeiske kulturarven. Forarbeidet skjedde i et eget utvalg, Bostad-utvalget, og ble publisert i en egen offentlig utredning, NOU 2007: 6, med tittelen Formål for framtida, før den ble enstemmig godkjent i Stortinget. Paragrafen kan oppfattes som bindende for resten av lovverket, og kan også mobiliseres mot urimeligheter i det.

Kant foreslo at der regler ikke er gitt, må de finnes opp. For at formålsparagrafen skal virke, kreves pedagogisk fantasi. Da tenker jeg ikke først og fremst på empati eller «mindfulness», men snarere på det Hannah Arendt kalte «å gå på besøk» visiting. Det er å se den andre i mangfoldets perspektiv, som et fremmedartet liv eller en mentalitet forskjellig fra ens egen, satt inn i en fortelling - en produktiv fiksjon om mennesker som lever et annerledes liv. "Visiting er derfor $i k k e$ å se verden gjennom den andres øyne, men å se med sine egne øyne fra en posisjon som ikke er ens egen ...» (Biesta, 2006, s. 91). Eller det kan dreie seg om det Herbart, i Allmenn praktisk filosofi (1808), kaller velvilje - tysk Wohlwollen og engelsk benevolence. Det er beredskap til å ville den andre godt i hans eller hennes person; til betingelsesløst og uten tanke på egennytte ville den andre vel: «Den gode vilje er god fordi den umiddelbart og uten motiv er god for den fremmede vilje». (Herbart, 1997, s. 169). Det dreier seg altså ikke om toleranse overfor den andre, som er betinget av den enes vilje, men om en desentrering som er åpen for og vil den andres vilje $i$ hans eller hennes person. For Herbart er denne ideen pedagogisk, det vil si den gjelder forholdet til 


\section{Løvlie}

barn i sin alminnelighet, og gir et perspektiv på den måten voksne kan møte barns egenvilje. Både visiting og velvilje er inspirert av Kants oppfordring til å sette seg i den andres sted, og kan føyes til Kants idé om verdighet som barnets «fødselsgave», den som gjelder universelt og uten hensyn til alder, klasse og etnisitet.

\section{Pedagogisk teori}

I «Omriss av pedagogiske forelesninger» (1835 og 1841) er Herbarts pedagogiske teori helt programmatisk formulert slik: «Pedagogikk som vitenskap avhenger av den praktiske filosofi og psykologi. Den første viser dannelsens mål, den andre veien, midlene og hindringene.» (Herbart, 1997, s. 186; 1980, s. 31). Denne definisjonen har ført til karakteristiske misforståelser. Med vitenskap menes ikke forskningsbasert viten og virke slik vi oppfatter dem i dag. Herbart skrev før den psykologisk empiriske forskningen var etablert, den opptrådte senere i århundret. Hans vitenskap var en blanding av filosofisk tenkning og psykologiske beskrivelser, basert på hans originale appersepsjonspsykologi, som foregriper psykologen Jean Piagets senere teori om forholdet mellom appersepsjon og assimilasjon. Definisjonen inviterer tilsynelatende til den arbeidsdeling mellom mål og middel som ble vanlig i Norge etter samfunnsvitenskapenes gjennombrudd etter 1945, da norsk pedagogikk vendte seg fra tysk Pädagogik og til anglo-amerikansk education. Mens læreplanen la de normative rammene, ble psykologien et verdinøytralt redskap til å realisere allmenne formål. Arbeidsdelingen ble sterkt kritisert i den såkalte positivismestriden i norsk pedagogikk, som brøt ut omkring 1970, og førte til kampen mot instrumentalismen i skolen. Striden gjorde det av med forestillingen om samfunnsvitenskapens objektivitet og midlenes nøytralitet - vitenskapen ble avslørt som «ideologi» og normativt tenkesett. Den bekreftet at empirisk kunnskap uten å ta det inn over seg grep inn i den sosiale veven og styrte pedagogisk praksis ut fra sitt særegne ståsted, som i tilfellet B. F. Skinners atferdsteori. Uskyldens tid var forbi. I dag er det allment akseptert at samfunnsforskere ikke har en nøytral posisjon i samfunnet, men står under en allmenn legitimeringstvang og må begrunne sine funn politisk. (Skjervheim, 1992).

Den siste generasjonen herbart-forskere har gjort det klart at Herbart nettopp ikke foreslo en mål-middel-modell (se Buck, 1985 og Benner, 1993). Hans pedagogiske teori kan tvert om leses som et argument mot mål-middel-tenkningen i pedagogikken. Teorien er relasjonell $\mathrm{i}$ den forstand at den omfatter vårt forhold til kunnskap og elevens forhold til læreren - denne dynamikken er blant Herbarts sentrale bidrag til pedagogikken. I en anmerkning til sitatet ovenfor gjør han nemlig straks klart at etikken, som dagliglivets moral, er nødt til å basere seg på erfaringen. Etikken må forholde seg til vitenskapens funn og til det sosiale liv, den kan ikke bare holde seg til det rene sinnelag og til formelle prinsipper. Den står i det virkelige liv og trekker på pedagogikkens historiske forutsetninger. Herbart støtter Kants idé om at mennesket står for prinsippene for moral og humanitet, men etikken begynner ikke med det kategoriske imperativ, men med det levde liv. Skal etikken virke må de moralske 
prinsippene prøves i konkrete situasjoner, den må kort sagt også gå erfaringens vei og støtte seg på psykologien.

På sin side, psykologien kan ikke basere seg utelukkende på egne teorier og observasjoner, men krever «rett forstått erfaring», mener Herbart. Erfaringer rett forstått omfatter refleksjon over mennesket som tenkende, villende og handlende vesen, og denne refleksjonen, til dels makeløst gjennomført av Kant, er normativ eller styrende for våre sosiale handlinger. Til det kommer at psykologien selv er historisk forankret og foranderlig. Dens teorier dør eller endrer seg. Med hurtige forandringer i sed og skikk, kunnskap og etikk, kan psykologisk kunnskap tape sin gyldighet og reduseres da til historiske kulisser - det er ingen som tror på frenologi eller skallemåling i dag. Etter omtalen av innledning i Omriss kan vi slutte at Herbart avviser skillet mellom en åndelig og sanselig natur, og med det også den pedagogisk villedende metaforen om de to naturer, menneskets animalske natur versus den åndelige. Å se danning som overgangen fra den første til den andre natur, er ikke bare å se bort fra den tidlige sosialiseringen i relasjonen mor-barn, men bygger på en dyp misforståelse av barnets natur. Verken Kant eller Herbart bruker denne metaforen, som ser bort fra barnets verdighet, forstår seg lite på assosiasjonspsykologien og gjerne ender $\mathrm{i}$ en tradisjonell paternalisme. Herbart tar eksplisitt avstand fra en «fatalisme» som sier at barnets utvikling er bestemt av natur eller av kultur - eller for den sakens skyld, av en laissez faire frihetsfilosofi som har kastet fortøyningene til virkeligheten; slike tanker «utelukker seg selv fra pedagogikken». (Herbart, 1980, s. 31). Og han har ingenting til overs for den type instrumentalisme som lever på tvedelingen mellom mål og middel, der midlene vurderes etter effektivitet og ikke inkluderes $\mathrm{i}$ etiske og pedagogiske overveielser. Herbart innfører for alvor relasjonstenkningen i pedagogisk teori. Han tar til orde for en hermeneutisk eller fortolkende praksis, der pedagogikken selv omformes i det gjensidige samspillet mellom lærer og elev, natur og kultur, teori og praksis.

Herbart vil ikke som Kant frakjenne naturen moralsk innhold og kraft. Herbart går med på at det finnes en tankeverden som gjør det mulig å formulere moralens høyeste prinsipp og mål, og det danner oppdragelsens ene betingelse. På den annen side, mennesket er og blir naturvesen, og det er all grunn til å ta høyde for individets følelser, opplevelser og erfaringer som den andre nødvendige betingelsen for moralsk oppdragelse. Hvorfor kan en ikke handle utelukkende ut fra moralske ideer? er Herbarts spørsmål. Svaret gir han selv: «Mennesket står midt i naturen, og er selv en del av den, i sitt innerste gjennomstrømmet av den. Det svarer på denne ytre makt gjennom sin egen indre, etter sin art og etter sitt vesen, først tenkende, så villende, så virkende. Gjennom dets vilje går naturens kjede. Men på ett bestemt sted for en bestemt vilje!» (Herbart, 1997, s. 55). Denne naturlige «indre makt» hører til den enkeltes individualitet og gjør seg gjeldende i nærmere bestemte situasjoner. Ta velvilje. Et imperativ om velvilje er ubestemt inntil det blir lokalisert til moralske situasjoner der mennesker engasjerer seg, øver velvilje og gir det konkret innhold. Den praktiske filosofien kan i mange tilfeller ikke gjøre krav på universalitet, det hjelper ikke alltid med allmenne råd i tilfeller der situasjonen krever individuelle moralske løsning, bestemt av tid og sted. I situasjonen har følelsene sin plass. 


\section{Løvlie}

I Allmenn praktisk filosofi (1808) oppsummerer han sitt syn slik: «Den [praktiske filosofien] må helt sikkert vise enhver til hans hjerte - ikke bare nå og da, men alltid nemlig til den finfølelse som ligger i vurderingen som gjelder tilnærmingen mellom virkeligheten og de moralske ideene.» (Herbart, 1997, s. 64).

\section{Formbarhet}

Herbarts relasjonstenkning spisses i begrepet eller formbarhet eller Bildsamkeit. Han begynner Omriss ved å erklære: «Pedagogikkens grunnbegrep er elevens formbarhet». (Herbart, 1980, s. 31). Den danske utgaven legger sin egen tolkning i selve teksten ved å oversette begrepet til «muligheten for å bli formet og dannet». Det gir grunn til å tro at det dreier seg om barnets plastisitet, noe som gjør eleven til emne for oppdragelsen, der eleven formes av læreren. Men da ender vi igjen i den instrumentell mål-middel-tenkningen som Herbart avviser. Han utdyper med å si at lærerens påvirkning begrenses av to forutsetninger: barnets «individualitet», dets særegne og unike temperament, og senere elevens «egenvilje og egne beslutninger»; dessuten tidens og stedets omstendigheter, det vil si lokal tilhørighet under en bestemt historisk periode, for Herbarts del opplysningen under det prøyssiske eneveldet. Deretter vender han seg fra elevens og til lærerens formbarhet, til «den yngre oppdrager», det vil si til den nye type lærer som «er i stand til å iaktta seg selv nøkternt og uten å foreskrive seg den ene aller andre ytterlighet» når det gjelder pedagogiske standpunkter. Læreren må ha et overblikk over hele den praktiske idélære eller tenkning, og «... for å kunne forstå sine iakttagelser og bedømme dem riktig, må han til stadighet ha psykologien til rådighet.» (Herbart, 1980, s. 32). Formbarhet går begge veier, den omfatter både lærer og elev i en praktisk giensidighet - Bildsamkeit er til det ytterste et relasjonelt begrep. Spørsmålet er hvor dypt denne gjensidigheten er tenkt.

La meg igjen minne om det grunnleggende trekket ved det såkalte pedagogiske paradoks: at det hersker en asymmetri mellom lærer og elev, mellom frihet og tvang. I min lesning er dette forholdet uløst i Rousseaus Emile, som preker en paternalisme under huslærerens milde tukt. Det er han som definerer elevens individualitet, og som skaper betingelsene for oppdragelsen ut fra innsikt i tiden og kunnskap om barnets psykologi. Perspektivet dreies nesten umerkelig fra barnets individualitet til lærerens oppfatning av den, og konflikten mellom den voksnes og barnets ståsted tapes av syne fordi barnet ikke kommer til orde. Læreren mener å ta elevens perspektiv, men realiseres sitt eget, og det perspektivet styrer konklusjonen om barnets natur. Det var Rousseaus selvbedrag og oppdragelsens evige fristelse. For forskningen er det ofte ikke et problem, fordi den nettopp søker kunnskap om objektet for sin virksomhet og ikke om seg selv - den er objektrettet og har ingen pretensjoner om å ta den andres standpunkt. Den pedagogiske tenkning er derimot tvunget til å giøre sin praksis gjennomsiktig for seg selv, det vil si for deltakerne $\mathrm{i}$ denne praksis - her betyr «pedagogisk» det samme som refleksjonsrettet. Kant giorde dette klart, og det holder jeg som hans store fortjeneste som pedagogisk tenker. Med begrepet Bildsamkeit tar Herbart et godt steg videre til fordel for psykologien 
som praktisk tenkning, en tenkning som tar for seg barnet sinn og oppfordrer læreren til desentrering og selvprøving. Ja, gjør han egentlig det? La oss forfølge Herbart i ett av hans tidligste skrifter: Om den estetiske framstilling av verden som oppdragelsens hovedoppgave (1804).

Der sammenlikner han læreren med en astronom, som stiller spørsmål til naturen, fastslår dens lovmessigheter og forholder seg til denne kunnskapen når naturen skal forklares. Læreren bør på samme måten ta utgangspunkt i barnets natur og de behovene som er med og bestemmer dets handlinger. Metaforen treffer heldigvis dårlig, for Herbart fortsetter med å beskrive barnets indre liv, altså verden sett fra barnets perspektiv. I barnets sinn treffer en ikke på en abstrakt 'transcendental frihet' (kritikk av Kant), men på en valgfrihet som «vi alle finner i oss selv» og som «vi ærer som det skjønneste uttrykk for oss selv», sier han. Oppdrageren bør ta utgangspunkt i den valgfriheten som barnet faktisk har, og som vi alle kjenner i oss selv når vi tar en beslutning. Han «bør sørge for at eleven selv finner seg som den som velger det gode og forkaster det onde», det er moralsk oppdragelse og forutsetning for å forme en individuell karakter. Herbart fortsetter med en sterk bekreftelse på barnets selvstendighet: «Denne høyningen til en selvbevisst personlighet må uten tvil skje i elevens eget sinn og fullbyrdes gjennom hans egen virksomhet; det ville være dumskap om oppdrageren skulle skape denne vesentlige kraft og la den påvirke den andres sjel.» (Herbart, 1997, s. 48f).

Her bekrefter han Kants tanke om barnets ukrenkelige indre, om retten til tankens frirom der den enkelte forholder seg til den indre moralske refleksjon, og omtaler som en negativ oppdragelse. Ved oppdragelsen og dens formål hefter en «negativ bestemmelse», sier Herbart, «som det er like viktig som den er vanskelig, nemlig å la individualiteten så ubeskadiget som mulig.» (Herbart, 1997, s. 71). Det er vel og merke hele tiden den moralske selvstendighet det står om her, om å ta den andres perspektiv og se bort fra egen nytte: «En kan fatte den ene og hele oppgave som oppdragelsen har, i begrepet moralitet.» (Herbart, 1997, s. 47). Det Herbart i Allmenn praktisk filosofi (1808) kaller «indre frihet» er ikke bare frihet fra ytre press, men frihet til selv å dømme om en lysten eller plikten skal følges. (Herbart, 1997, s. 165). Lydighet er en viktig dyd, men den som lyder må ha prøvd og vurdert påbudet, det vil si han må gjøre det til en befaling som ikke bare gjelder utenfra, men gjelder for ham selv som befaling innenfra.

Hvordan kan Bildsamkeit oppsummeres? Begrepet bryter med Kants to-verdenlære, den mellom tanke og ting. Moralen hører til én og samme livsverden, den er dømt til å bli realisert i et samfunn bestemt av tradisjon og sedvane, tid og sted. Begrepet viser til det «ubestemte» og uferdige som ligger i elevens (gryende) individualitet og som går over til «fasthet» eller karakter i oppdragelsen. Det dreier seg om barnets individualitet snarere enn om dets plastisitet, mer om det formende samspill enn om lærerens dominans, fjernt fra enhver indoktrinering. Bildsamkeit er ikke en bestemt egenskap ved eleven, men beskriver eleven i relasjon til læreren i et oppdragende samarbeid. Analysen gjelder ikke individet $\mathrm{i}$ og for seg, men individeti-samspill, som et felles erfaringsløp der begge partene lærer i tenkning og handling. Herbarts forsøk på å se filosofi og psykologi i tandem er et gjennomtenkt bidrag til 


\section{Løvlie}

moderne pedagogikk, og det realiserer Wilhelm von Humboldts bare skisseaktige idé om danning - Bildung - som å bringe selvet og verden i det livligste og mest skapende samspill. Er det pedagogiske paradoks nå oppløst i denne tenkningen, møtes oppdragerens intensjon og elevens selvstendighet endelig i et forhold der motsigelsen mellom frihet og tvang er opphevet og forsoning er nådd? Neppe, og det skyldes at motsigelsen tilhører forholdet mellom barn og voksen, og finnes $\mathrm{i}$ asymmetrien $\mathrm{i}$ oppdragelsen. Og det skyldes ikke minst Herbarts assosiasjonspsykologi, som tegner et læringsforløp uten ende og konklusjon.

Kritikere har pekt på at Herbarts didaktikk eller undervisningslære nettopp ikke består den praktiske prøven, og at særlig Omriss - hans seneste verk - faktisk introduserer en høy grad av metode og lærerstyring. Det han vinner i teorien, synes han altså å tape i praksis. Plassen tillater meg ikke å gå nærmere inn på kritikken av Herbarts didaktikk, ei heller på de såkalte herbartianernes systematisering av hans ideer. Dessuten er jeg mer opptatt av det han tenker om friheten og dens begrensninger. Læring uten ende setter framtiden fri, den gir forventning og håp om frihet. En annen frihet finnes, hvis vi ser etter, i forholdet mellom teori og praksis, nærmere bestemt i bindestreken i sammenstillingen teori-praksis. Bindestreken blir akkurat som konjunksjonen eller bindeordet og ofte oversett, det betyr tilsynelatende ikke noe i seg selv. Men det lille, unnselige tegnet røper noe mer. Bindestreken binder, det er så. Men den kan leses både som bånd og brudd, avgrunn og bro. Hvis Herbarts første fortjeneste ligger i begrepet Bildsamkeit, så er hans andre store fortjeneste å la oss se at båndet og bruddet mellom teori og praksis skjærer like gjennom oppdragelsen, og at i den skjæringen finnes også pedagogikkens mulighet og åpning. Han inviterer til oppdagelsesferd, til å se hva bruddstreken i teori-praksis har å si i pedagogisk tenkning. Herbart gir også bruddstreken et navn: takt. La meg foreslå takt som nok et moment i den såkalt negative oppdragelse etter Rousseau. Med takt stiller han spørsmål ved en idé - og en fordom - som fortsatt er med oss: at oppdragelsens lykkes om vi skaper en sømløs enhet av teori og praksis, av vitenskap på den ene siden og undervisning og oppdragelse på den andre. La oss ta utgangspunkt $\mathrm{i}$ at takt verken hører til vitenskap eller praksis, men finnes mellom dem $i$ et tredje. Hva er det tredje?

\section{Takt}

Herbarts tenkning er så vidt jeg kan se en invitasjon til å forlate det uføret en kommer $\mathrm{i}$ ved å tro at motsetningen mellom teori og praksis kan forsones. For en drøy generasjon siden var det troen på at forskningsresultater kunne omsettes direkte til klasserommet. I dag er det troen på ledelses- og kontrollstrategier som skal sikre læring i skolen. Det første ble som sagt kalt positivisme, det andre kan kalles troen på regelfølge og henger sammen med rettsliggjøringen av skolen, og kan kalles den nye instrumentalisme. Takt er et argument mot tanken om at alt er vel dersom abstrakt planlegging og styring løper godt. På terskelen til den empiriske vitenskapens tidsalder presenterte den 26-årige Herbart i 1802 motsetningen i et kortfattet 
skrift, nærmest en programerklæring, med tittelen "Den første forelesning om pedagogikk". I den trekker han et skille mellom viten og kunnen, mellom pedagogikk som vitenskap og oppdragelse som kunst - kunnen og kunst har felles språklig opphav. La oss gå til Herbarts tekst, der han setter «teori» på sin korteste formel, som en "samordning av læresatser som utgjør en tankehelhet" (Herbart, 1997, s. 43). Denne samordningen skjer mellom filosofien og hermeneutikken, med hjelp fra strenge vitenskaper som matematikk og fysikk, den vitenskap som får prestisje på 1800-tallet og etter hvert bestemmer våre dagers samfunnsvitenskaper.

Mens vitenskapen samordner sin viten etter metoder for systematisk prøving med hensyn til forskningen selv, er kunst som kunnen derimot «en sum av ferdigheter som må forenes med hensyn på å nå et visst mål» i det praktiske liv. Herbart mente at oppdragelse og undervisning knapt kan realiseres uten en praktisk lærerutdanning. Men - og det er det mer prinsipielle standpunktet - det er ikke gitt at pedagogisk kunnen lærer av sine feil. Kunnen som overlevert pedagogisk praksis har satt sine grenser. Den holder på tradisjonelle forestillinger, gjentar gjerne sine rutiner og sine mistak. Den har ikke noe godt blikk for alternativer, har svak basis i kritisk kunnskap, og holder seg til begrensede erfaringer. Han har mye rett i det. Det var ikke tradisjonen, men prinsipiell humanistisk tenkning som tvang fram utviklingen fra spanskrøret til moderne reformpedagogikk, samtidig som ny praksis ble drevet fram, blant annet av folk som hadde lest Rousseau og ikke tålte at skolen fortsatt banket kunnskapen inn i barn. Der praksis hersker, overlever gjerne fortidens læresetninger, der teori dominerer, fanges en lett av tankens viderverdigheter, det filosofen Jon Hellesnes har kalt sprenglærd toskeskap. Men god teori kan ruske opp i overlevert praksis og opplyst praksis kan tøyle teoriens arroganse.

Nå introduserer Herbart det tredje moment, som er mellomleddet som formidler mellom teori og praksis. Han beskriver mellomleddet som «... hurtige vurderinger og beslutninger som ikke går fram med vanemessig slapphet», men heller ikke kan treffe det individuelle tilfellet «med streng konsekvens og i full oppmerksomhet om regelen, slik en fullkomment gjennomført teori idet minste burde gjøre.» (Herbart, 1997, s. 44). Ikke særlig opplysende sitat, må jeg si! Men argumentet sier at reglene ikke treffer det unike eller enestående, og at den empiriske vitenskapen ikke bør gi spesifikke metodiske anvisninger for praksis, for praksis krever en over-settelse, bokstavelig talt, fra viten til handling. Her trer takt inn, altså noe som ikke er overlatt til tradisjon eller teori, men snarere gir seg til kjenne som evnen i å oppfatte hva som trengs og kreves i konkrete situasjoner. Takt oppstår i rommet mellom teori og tradisjon, nærer seg av begge, men identifiserer seg ikke med dem. Den hentes ut av finfølelsen for det som kreves i situasjoner der viten er relevant, men ennå ikke relatert til saken der og da. Vi har for eksempel tester og sjekklister for å diagnostisere barn med ADHD, men diagnosen er omstridd og skolens vurderinger kan slå feil. I dette urene farvann må skolen basere seg på skjønn, på kunnige og kyndige lærere som vet å ta både kunnskapens og elevens perspektiv. Det er nyskaping i det lille, men viktige format. Herbart beskriver takt som et faglig begrep, det er skjønn som 


\section{Løvlie}

setter vitenskap og praksis i spill. Han er riktignok ikke eksplisitt opptatt av takt som empati eller mental tilstedeværelse eller mindfulness. Men den som har takt reagerer på den andres følelser, klarer å ta stemningen i et klasserom og handler etter denne finfølelsen. Hun handler etter regler, men også etter intuisjon og etter menneskelige og pedagogiske overveielser. Takt er bruddstreken som der og da holder reglene fra livet. Den er også bindestreken som venter på en konkretisering. Den er mellomrommet, pausen og ettertanken - del av det vi kaller pedagogisk fantasi.

Takt er med andre ord en praksis for det som er i emning, som blir til i det den fullbyrdes, som når et spørsmål gir et uventet svar, eller et forhold bekreftes eller avkreftes ved en ny innsikt og samhørighet. Takt forberedes gjennom teoretisk kunnskap og praktisk erfaring, men er ikke identisk med dem. Teori-praksisproblemet kan løses ved å gi teorien en autoritet og praksis en realitet, men det er skjønn som formidler mellom dem. Kravet om skjønn vender han eksplisitt mot læreren, og lærerutdanningen: «... ved overveielser, ettertanke og etterforskning, giennom vitenskap skal oppdrageren forberede - ikke bare sine framtidige handlinger i enkelttilfeller, men snarere sitt sinn, sitt hode og sitt hjerte til riktig å motta, oppfatte og fornemme de fenomenene som venter ham, og den situasjon som han har kommet i». Skjønn skal tjene teorien og styre praksis. Bare «i handling lærer man kunsten, oppnår man takt, ferdighet, behendighet og dyktighet», men den bør være vitenskapelig fundert: det finnes en «kunstens forberedelse gjennom vitenskapen» (Herbart, 1997, s. 45).

Å tenke ut fra oppdragelsen er Herbarts fremste bidrag til moderne pedagogisk tenkning. Han blinket ut området for denne tenkningen ved å beskrive Bildsamkeit og takt, relasjon og handling basert på vitenskapelig arbeid. Som John Dewey senere giør, oppfatter Herbart pedagogikken som stedet der filosofi, natur- og samfunnsvitenskapen kan samles som "rett forstått erfaring", altså en praksis. I en anmerkning til definisjonene av teori og praksis giør han det straks klart at praktisk filosofi er nødt til å basere seg på erfaringen, den må forholde seg til faktisk forutsetninger og reelle situasjoner. Men regler alene gir ikke etikken ansikt og lidenskap. Skal etikken virke, må prinsippene svare til konkrete situasjoner og deres krav, den må gå erfaringens vei og begi seg livet i vold. Takt er en realisering av bindestreken, av brudd og bånd, den er altså en praksis. Men den er ikke en metode i lærerens verktøykasse. Den trer inn der reglene ikke strekker til, som dannelse og holdning, og som det umiddelbare, ennå utenkte grepet på situasjonen. Kan takt læres? Vel, det utenkte og uforutsette kan selvsagt ikke læres, men det kan forberedes ved å oppleve, vurdere og tenke over situasjoner der fornemmelsen sviktet og grepet glapp, og over de lykkelige gangene der grepet satt. Takt er et annet ord for lærerens enestående råderom, for en frihet som skolen ikke kan være foruten.

\section{Forfatterpresentasjon}

Lars Løvlie er professor emeritus ved Institutt for Pedagogikk, UiO. Han har tidligere skrevet om den estetiske erfaring, selvet i det postmoderne og betydningen av internett for vår selvbeskrivelse, men er nå mer opptatt av å skrive om pedagogikk i lys av den europeiske danningstradisjonen, med kritisk avstand til trekk ved dagens tenkning om utdanning og til det utdanningspolitiske regimet som er satt i verk etter årtusenskiftet. 


\section{Referanser}

Benner, D. (1993). Die Pädagogik Herbarts. Weinheim: Juventa Verlag.

Biesta, G. J. J. (2006). Beyond learning. London: Paradigm.

Buck, G. (1985). Herbarts Grundlegung der Pädagogik. Heidelberg: Carl Winter.

Herbart, J. F. (1997). Systematische Pädagogik. Band 1: Ausgewählte Texte. Benner, D. (Hrsg.). Weinheim: Beltz.

Herbart, J. F. (1980). Pedagogiske forelesinger $i$ omrids (1980). København: Nyt Nordisk Forlag.

Skjervheim, H. (1992). Filosofi og dømmekraft. Oslo: Universitetsforlaget. 